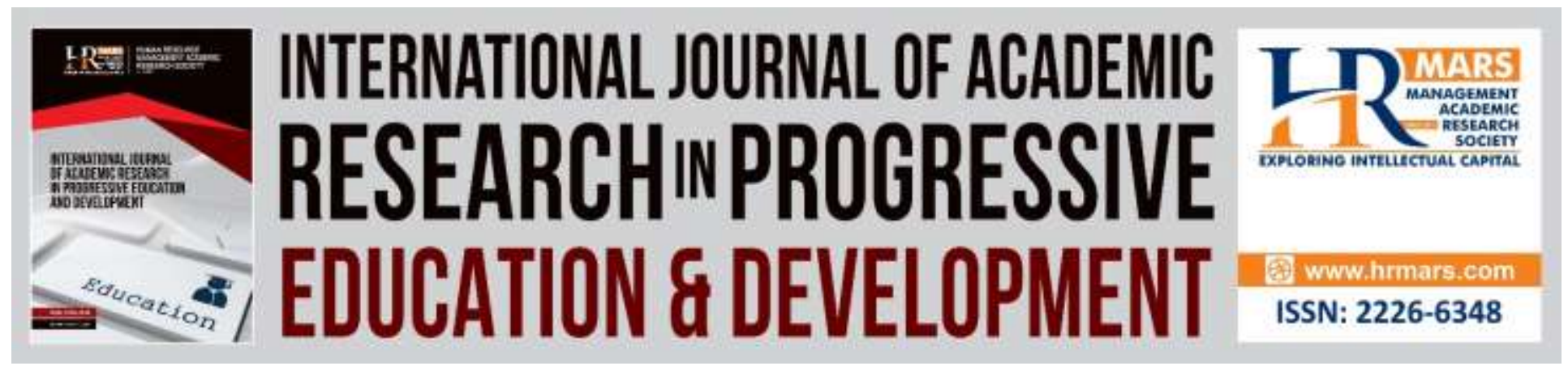

\title{
The Influence of Learning Organization Practices toward Teacher Leadership among Secondary School Teachers in State of Perak
}

\author{
Mahaliza Mansor, Jamal @ Nordin Yunus, Fanny Kho Chee Yuet, Khalip \\ Musa, Mohd Asri Mohd Noor
}

To Link this Article: http://dx.doi.org/10.6007/IJARPED/v8-i4/6438

DOI: 10.6007/IJARPED/v8-i4/6438

Received: 16 July 2019, Revised: 11 August 2019, Accepted: 06 September 2019

Published Online: 26 September, 2019

In-Text Citation: (Mansor, Yunus, Yuet, Musa, \& Noor, 2019)

To Cite this Article: Mansor, M., Yunus, J. @ N., Yuet, F. K. C., Musa, K., \& Noor, M. A. M. (2019). The Influence of Learning Organization Practices toward Teacher Leadership among Secondary School Teachers in State of Perak. International Journal of Academic Research in Progressive Education and Development, 8(4), 91-102.

Copyright: (C) 2019 The Author(s)

Published by Human Resource Management Academic Research Society (www.hrmars.com)

This article is published under the Creative Commons Attribution (CC BY 4.0) license. Anyone may reproduce, distribute, translate and create derivative works of this article (for both commercial and non-commercial purposes), subject to full attribution to the original publication and authors. The full terms of this license may be seen

at: http://creativecommons.org/licences/by/4.0/legalcode

Vol. 8(4) 2019, Pg. 91- 102

http://hrmars.com/index.php/pages/detail/IJARPED

JOURNAL HOMEPAGE

Full Terms \& Conditions of access and use can be found at http://hrmars.com/index.php/pages/detail/publication-ethics 


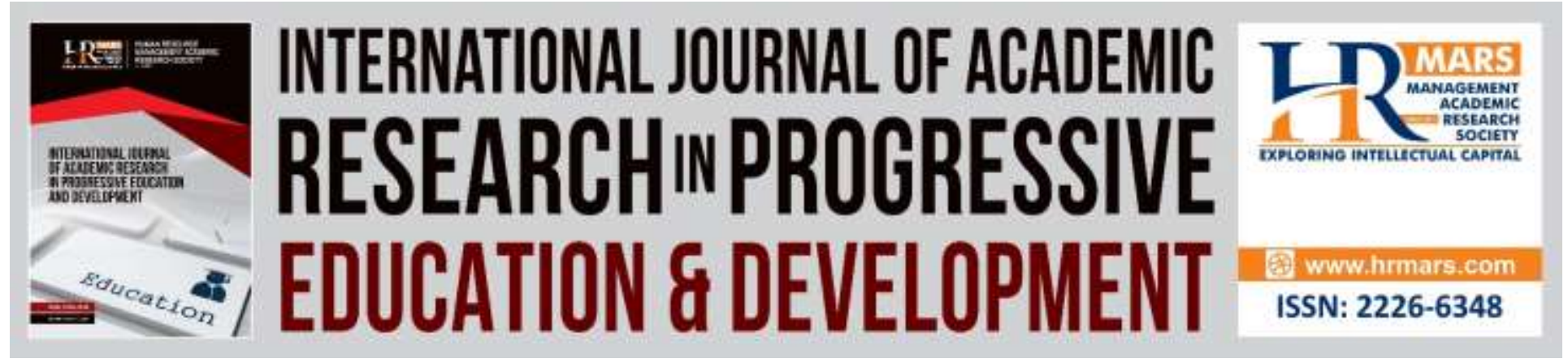

\title{
The Influence of Learning Organization Practices toward Teacher Leadership among Secondary School Teachers in State of Perak
}

\author{
Mahaliza Mansor, Jamal @ Nordin Yunus, Fanny Kho Chee Yuet, \\ Khalip Musa, Mohd Asri Mohd Noor \\ Faculty of Management and Economics, Sultan Idris Education University, Tg Malim
}

\begin{abstract}
This study focused on the influence of learning organization practice toward teacher leadership among secondary school teachers in the state of Perak. The quantitative approach of descriptive correlational design has been used in this study. The sample consists of 400 teachers from 50 secondary schools in Perak. The data were analyzed using mean and multiple regression. Findings indicate that the level of organizational learning practice (mean $=3.78$ ) is at a high level. In addition, the results show that the learning organizational variables, which is individual learning $(\beta=0.57, p=0.05)$ is the main influence on teacher leadership and followed by global learning ( $\beta$ $=0.25, p=0.05)$. A total of 53 percent of variation in teacher leadership is explained by learning organizational variables. In conclusion, the practices of learning organization definitely influence teacher leadership secondary school in Perak. The implications of the study show that learning organization practice can enhance the teacher leadership and it is appropriate to be practiced in all schools for the development of the school.
\end{abstract}

Keywords: Learning Organization, Teacher Learning, Teacher Leadership.

\section{Introduction}

International studies show that teacher quality is the most significant school-based factor in determining student outcomes. Although there are excellent teachers in Malaysia's education system, the study of AKEPT 2011 found that only 50\% of the teaching was delivered effectively (KPM, 2012). This means that the delivery of subjects does not involve the students adequately, and the teaching method is more passive and does not focus on higher-order thinking skills. This statistic also shows the big challenges that will be faced, because there are approximately 60\% of teachers today will continue to teach for another 20 years (KPM, 2012). These teachers are around 25 to 40 years who will still teaching for the next 20 years (KPM, 2014; Ahmed, Khalid, N., Ammar, \& Shah, (2017).

Therefore, Ministry of Educaton (KPM) (2012) through Malaysian Education Development Blueprint has enhanced the quality of school-based continuous professional development since 
2013. Most of these programs are already and still being conducted at the school level because the school-based training has proven to be very effective as one of the continuous professional learning methods. This program allows teachers to continuously improve their level of skills as well as their knowledge that in line with the expected competence of a teacher. However, more thorough research on the learning organization practice consists of individual learning, team learning, organizational learning and global learning elements (Marsicks \& Watskin, 2003) which are also teachers' professional learning (Feimen-Nemser, 2012) suitable and effective with the context (Avalos, 2011) is still less implemented especially for teachers in secondary school (Rosnah \& Faizal, 2012; Ahmed, Majid, \& Zin, 2016).

Hence, this study will explore more about the level of organizational learning practice that consists of individual learning, team learning, organizational learning and global learning among teachers. In addition, this study also explores about the learning organization practice that can influence teacher leadership (Hunzicker, 2012) among secondary school teachers in the context (Guskey, 2009; Feimen-Nemser, 2012).

\section{Literature Review}

This section will explore more about the two variables, which is learning organization practice and teacher leadership as well as their dimensions.

\subsection{Learning organization practice}

Learning organization refers to a group of people who constantly strive to continuously improve their ability to achieve the desired success (Senge, 1990). However, Watkins and Marsick (1993) point out that learning organization is the organization that learning continuously for the purpose of achieving progress or development and having the capacity to change on its own. Learning organization should be more flexible and ready to face the latest changes to meet the demands of world's reforms. Besides that, they also believed that the organization means 'tools or instruments' that are geared towards collective learning activities, and share experiences (Marsick, 1996). Hence, proper learning organization practices are implemented therefore school communities can constantly learning to achieve improvement and have the capacity to evolve in tandem with current challenges.

This study uses the Watkins and Model (1993) which consists of individual learning practices, group learning practices, organizational learning practices and global learning practices. Watkins and Marsick (1993) have outlined four stages of learning process so that the organization will become a learning organization, adapts to change and achieves the goal of continuous improvement in the organization. The learning process in this model starts from the bottom, which is someone begin to learn individually and then they are relate to larger and broader social units, communities and environments (Watkins \& Marsick, 1993; Garvin, Edmondson \& Gino, 2008). 
Vol. 8, No. 4, 2019, E-ISSN: $2226-6348$ @ 2019 HRMARS

\section{Individual Learning Practices}

The first dimension of learning is to create continuous learning opportunities and to encourage inquiries and dialogues in the Watkins and Model (1993) which described the individual level of learning practices in the organization. Watkins and Marsick (1993), Senge (1990) and Garvin et al. (2008) argued that individual should be responsible for being lifelong learners in the context of learning organization. This statement is supported by Honan (2012) who think learning enables teachers to become active lifelong students and provide teachers with the opportunity to improve their practice as well as the practice encompassing the entire of school organization.

Furthermore, Watkins and Marsick (1993) point out that the organization should also provide opportunities for ongoing individual learning activities. This statement is in line with Marzano's (2012) which states that principal can help teachers to improve learning practices by providing teachers with opportunities to discuss; regularly interact with group members and organizations to identify issues regarding curriculum, assessment, student achievement; ensuring that teachers have a formal role in the decision-making process for school improvement. However, there are various approaches can be used by organizations to encourage continuous learning. According to Avalos (2011) teachers are involved in two forms of learning, which are formal and informal. Both of these types of learning enable teachers to expand their professional competence that contains their own beliefs, self-regulatory skills, motivation and knowledge (Avalos, 2011).

\section{Group Learning Practice}

The third dimension of learning is encouraging collaborative and team learning practices within the organization which is also can be described as the practice of team level learning. Collaborative learning developed as the team members learn designing, redesign, trying something new, doing something beyond expectation and creating integrity perspective (Watkins \& Marsick, 1993; Garvin et al, 2008). This statement is in line with Spillane's (2012) that, in effective learning practices, teachers and principals share their knowledge and expertise as well as engage in continuous learning processes to achieve school improvement.

\section{Organizational Learning Practices}

The fourth dimension of learning is creating a system for acquiring and sharing learning practices and sharing the power to achieve goals together, that is described in Watkins and Model (1993). Shared learning practices and creating the system can be accomplished in two ways. The first approach is technology-based initiatives where organizations can maintain systems and share their learning practices. Meanwhile, the second approach is by using low technology that can be achieved by restructuring organizational citizen jobs and their assignments (Marsick, 1993). This is in line to Guskey (2014), which teachers will normally try new approaches to teaching students; collect information from the experts, about how to apply the approaches to teach students and finally make decision about the changes that need to be done to improve student success.

Next, power sharing means "authorize". Agreement in shared vision; provide resources needed to achieve the vision; for success; forming own working group; equating organizational hierarchy and developing a culture that supports decision-making is one of the strategies of empowerment in the organization. There is evidence showing that student achievement is more likely to increase when leadership is shared and teachers are empowered in decision-making 
related to teaching and assessment practices (Surendran, 2013). On top of that, power sharing also allows interactions between individuals, teams, departments who have respected each other, created the spirit of collaboration and inquiries, being honest and safe and trusting each other will grow every day (Marsick, 1993; Garvin et al, 2008). The success of collaborative learning will occur when teachers have the power to analyze data with the group members and are trusted by administrators at school. According to Stoll (2011), the role of principal in collaborative learning of teachers is to encouraged. Stoll believes that principal can improve the collaborative learning of teachers by supporting improvements in self-reflection and time for learning among teachers (Cooper, 2014).

\section{Global Learning Practice}

The fifth dimension of learning is creating a system for linking an organization with its environment which also can be describes as global-level learning practices. At this stage, the organization learns by linking its system with its internal and external environment. The relationship and integration of this organizational system respond to all members of the organization and their work needs through both environments (Marsick, 1993; Garvin et al, 2008). Besides, the external environment also involves competitors, as well as government policies that have impact directly or indirectly on the organization. This is in line with the opinions of Fairman and Mackenzie (2014) and Swanson, Elliott and Harmon (2011), teachers need to collaborate with the community and parents and share the tasks outside the school as well as professional organizations, such as the Education Department, Ministry of Education and UNESCO.

\section{Teacher Leadership}

Teacher leadership is a set of skills possessed by teachers, which is able to influence students in and out of the classroom (Danielson, 2006). According to Katzenmeyer and Moller (2009), teacher leadership is the ability of a teacher to lead the students in and out of the classroom, contribute to the leaders' as well as teachers' learning communities and influenced others towards the continuous improvement of the practice. Meanwhile according to York-Barr and Duke (2004), teacher leadership is a process whereby teachers individually or collectively influenced their colleagues, principals and school communities to improve teaching and learning practices with the aim of improving student learning and academic achievement. Therefore, teacher leadership can be achieved by maintaining teachers ' focus on student learning, acquiring lifelong learning for themselves, using facilities and presentation skills, engaging people through shared vision, developing and maintaining relationships, work with intergrity and planning as well as organizing works (Bowman, 2004; Moller, Childs-Bowen \& Scrivner, 2001).

Macbeath (2012) in their study also demonstrated that high leadership skills had a great impact on producing quality teachers in carrying out the duties of teaching profession in improving student achievement. Teacher leadership also can produce experienced teachers with a high degree of collaboration towards students excellence. This is in line with Muijs, Amstrong (2013) view, that leadership skill such as diseminate good teaching practice with collegues can increase the skills of the teachers of the particular school. Therefore, the leadership skills of the teacher should be emphasized and improvised with the new innovations and discoveries. 
Teacher leadership also involves practicing professional learning for continuous improvement. In this context, teachers will be able to express their opinions in efforts to achieve school vision and mission (Muijs et al., 2013). Teacher leadership also provides space for teachers to share knowledge beyond the boundaries. This can be done with the involvement of teachers in various teacher leadership programs as policy makers at the ministry level where teachers have the opportunity to give their views (Lead, 2013). Teachers who share the same vision with school management exhibit an attraction when teachers play their role as a leader. However, there are also situations where teachers are frustrated if the school has a non-uniform and blur vision (Berg, Bosch \& Souvanna, 2013). According to Rovere (2013), the role of teachers has been developed and now the teacher leadership plays a key role in co-operation with the administrator in providing continuous professional learning opportunities for their colleagues. Therefore, teachers should be provided with leadership skills through teacher learning practices so that they are able face challenges in the process of improving teaching and learning.

Study by Poekert (2012) shown that, teacher leadership has strong relationships with professional learning or teacher learning. This can be seen through the main elements of the teacher's focus, especially in improving the level of teaching practice and academic performance of students (Poekert, 2012). Therefore, effective teacher learning or learning organization practices will produce skilled and knowledgeable teachers. Fairman and Mackenzie (2012) studies shown that teachers that have internal motivation will engage in teacher learning continuously. In addition, teacher leadership also focuses on the commitment of teachers to learn for the purpose of improving student learning (Fairman \& Mackenzie, 2012) as well as to improve the learning organization practice or teacher learning (Poekert, 2012). Therefore, based on the literature review, it can be said learning organization practice can influence teachers to improve their leadership skill in improving the schools effectively.

\section{Research Method}

Sampling

This study is a descriptive-correlation survey using a questionnaire to collect data. A total of 120 trained teachers from three secondary schools in Mualim District, Perak have been selected in pilot study to perform preliminary validity test. Meanwhile the population of this study consists of trained teachers in fifty secondary schools in Perak. The population is 15,271 (Perak, 2017). Thus, 400 teachers were selected using stratified random sampling and systematic random sampling of the population (Fowler, 2009; Gay, Mills \& Airasian, 2009).

\subsection{Construction, Validity and Reliability of Instruments}

Pilot study was carried out to ensure the validity of the face and determine the reliability coefficient of the instrument. (Mansor, Norwani \& Yunus, 2011). Instruments used to measure teacher's view of learning organization practise and teacher leadership have been adapted by previous researchers. The previous study was the study of Marsick and Watkins (2003) for the practice of learning organization and the instrument for teacher leadership was adapted from the Katzenmeyer and Moller (2009). The instrument consists of 3 sections: Part A: Learning Organization Practice, Part B: Teacher Leadership and Part C: Demographics. The reliability coefficient value for both instruments are as in the Table 1 below. 
Table 1. Reliability of Instrument of Study.

\begin{tabular}{lllll}
\hline Variables & Sub-scales & $\begin{array}{l}\text { Number of } \\
\text { Item }\end{array}$ & $\begin{array}{l}\text { Alpha } \\
\text { Value }\end{array}$ & Coefficient \\
\hline Learning & & 28 & .96 & \\
Organization & 5 & & .69 \\
& Individual Learning & 5 & & .84 \\
& Group Learning & 7 & & .83 \\
& Organizational & 11 & & .95 \\
& Learning & & & \\
& Global Learning & & .96 & \\
Teacher Leadership & & & .77 \\
& Self awareness & 4 & & .89 \\
& Communication & 3 & & .87 \\
& Diversity & 5 & & .88 \\
& Instructional & 6 & & \\
& Efficiency & 6 & & \\
& Continuous & 4 & & \\
& Improvement & & & \\
& Self Organization & & & \\
\hline
\end{tabular}

\section{Findings}

4.1 Learning Organization Practice Level at the Secondary School in Perak.

Table 4.5 below shows the mean score distribution of learning organization variables. Overall, the level of organizational learning practice is at high levels in the schools involved with the study. However, the use of global learning was higher at 3.98 compared with other learning, while individual learning was at the lowest level of 3.62. Besides, the use of global learning was higher at 3.98 compared with other learning, while individual learning was at the lowest level of 3.62.

Table 2. Mean Score and Deviation of Learning Organization Standard.

\begin{tabular}{lllll}
\hline Learning Dimension & $\mathrm{n}$ & Mean & $\begin{array}{l}\text { Standard } \\
\text { Deviation }\end{array}$ & Level \\
\hline Individual Learning & 400 & 3.62 & .54 & Moderate \\
Group Learning & 400 & 3.86 & .58 & High \\
Organizational & 400 & 3.65 & .60 & Moderate \\
Learning & 400 & 3.98 & .66 & High \\
Global Learning & 400 & 3.78 & .42 & High \\
Learning Organization & & & & \\
\hline
\end{tabular}

Learning Organizations Practice toward Teacher Leadership.

According to Table 3, the results of multiple regression analysis involving four independent variables on the dependent variable of the leadership of the teacher. The findings show that only two dimensions of learning organization that influence teacher leadership, which is individual 
learning and global learning. Both of these elements are influential factors that have significant correlations and contributions to teacher leadership. The elements of this learning organization account for $53 \%$ of the teachers' leadership.

The learning organization dimension that became the predictor of the leadership of the teacher in this analysis was individual learning $(\beta=.57, t=13.35$ dan $p<.05)$. This model contributed $49.30 \%(r=.70)$ variation in teacher leadership. The second predictor was global learning $(\beta=.24, t=5.57$ and $p<.05)$ and contributed $3.70 \%$ to teacher leadership. The combination of both individual learning variables and global learning contributes $53.00 \%(r=.73)$ of variance changes in teacher leadership $[F(2,397=233.49, p<.05]$. This regression analysis explains the practice of learning organization, which only predicted by individual learning and global learning that has correlation and gives influence to the leadership of the teacher.

\section{Conclusion and Discussion}

Overall, the level of organizational learning practice is at a high level in the schools involved in this study. However, the use of global learning was higher at 3.98 compared with other learnings, while individual learning was at the lowest level of 3.62. The mean score for the group learning was 3.86 and the mean of organizational learning was 3.65. The findings show that teachers perceived that they are tending to learn more from the leader's instructions. Today's teachers are also found to be no longer studying alone, that we can see the practice of individual learning and other learnings from the finding of the study. This finding is in line with the findings of Marsick and Watksin (2003) and Avalos (2011) studies that teachers are sensitive to learning, especially through the direction of the superiors or KPM.

The findings also show that only two elements of learning organization influence teacher leadership, which is individual learning and global learning. Both of these elements are influential predictors that have significant correlations and contributions to teacher leadership. These learning organization elements contributed $53 \%$ of the teachers' leadership. The learning organizational element that became the major predictor of teacher leadership in this analysis was individual learning $(\beta=.57, t=13.35$ and $p<.05)$. This model contributed $49.30 \%(r=.70)$ variation in teacher leadership. The second predictor was global learning $(\beta=.24, t=5.57$ and $p$ $<.05)$ and contributed $3.70 \%$ to teacher leadership. The combination between individual learning and global learning contributes $53.00 \%(r=.73)$ variation changes in teacher leadership $[F(2,397=$ $233.49, p<.05]$. The findings of this study show that only individual learning and global learning elements are teacher learning that affects their leadership significantly. This is in line with the findings of Marsick and Watskin (2003) and Hunzicker (2012) which explain that learning organizations have indeed influenced the leadership of a teacher or the performance of an organization. In Perak, however, their teacher view only individual learning and global learning are the catalysts in improving their leadership. Teachers receive instruction from principals or KPM and carry out these instructions individually, this is synonymous with the centralize education system in Malaysia.

The implications of the study showed that the practice of learning organization is the change agent that helps teachers' daily work. Individual learning and global learning practices can develop teacher as a leader and further improve the quality of the teacher (Marsick \& Watskin, 2003; Poekert, 2012; Fiemen-Nemser, 2012) which is the basis for improvement of teaching 
professionalism. Thus, teachers need to continuously improve their knowledge by conducting school-based learning to support the government's aspiration to ensure Malaysia as a developed nation by creating human capital that is able to compete in the global arena as envisioned by the Malaysian Education Development Plan (2013-2025).

The incentives and supports given by the administrators to the teachers to carry out schoolbased learning are necessary. Administrators should support teachers to conduct learning by providing space for learning activities and encouraging teachers to engage in deep learning. In addition, recognition is one of the factors that influence the interest of teachers to learn continuously. Recognition with affirmation, such as praises, recognizes performance achievement and giving opportunities for teachers to attend seminars can motivate teachers to carry out learning at work. Therefore, principals should also ensure that the school in-house training secretary always provides updated information on the Training Management System, Ministry of Education Malaysia (SPL KPM) so that every teacher can fulfill at least 7 days of learning/training, that is the minimum number of learning days set by KPM.

The State and District Education Department should plan the activities at district and state level to expose teachers on the importance of learning. E-learning courses and workshops, such as I-Think Map and Massive Open Online Courses (MOOC), are the online courses aimed at massive interactive participation and open access through websites can be held regularly so that teachers' skills and knowledge can be improved continuously. Teacher Professional Development Programs need to be streamlined by adding selective topics to the curriculum that allows teachers to have an in-depth knowledge of the importance of learning organization. Furthermore, the program also needs to be set up as to enable teachers to have skills in conducting learning by using electronic media. Besides that, the teachers learning performance can be used as a key criterion for the selection of teachers for promotion such as teacher leader.

This study is limited to four dimensions of learning, that are individual learning practice, group learning practice, organizational learning practice and global learning as suggested by Seven Imperatives Model by Watkins and Marsick (1996). Therefore, it is suggested that future researchers to use other learning organization models as variables to study the learning practices conducted by school administrator as well as the educators, especially primary school teachers. Lastly, this survey measuring tool needs to be re-tested with different samples and situations to ensure that it fits and meets the goals of in-depth research. The scope of this study can also be further expanded by increasing the role of school administrators as mediator variables as well as academic achievement of pupils as dependent variables.

\section{Acknowledgement}

This research is funded by UPSI University Research Grant (GPU 2017-0166-106-01).

\section{Corresponding Author}

Jamal @ Nordin Yunus, Faculty of Management and Economics, Sultan Idris Education University, Tg Malim, Malaysia. Email: jamal@fpe.upsi.edu.my 
INTERNATIONAL JOURNAL OF ACADEMIC RESEARCH IN PROGRESSIVE EDUCATION AND DEVELOPMENT

Vol. 8, No. 4, 2019, E-ISSN: 2226-6348 @ 2019 HRMARS

\section{References}

Ahmed, U., Khalid, N., Ammar, A., \& Shah, M. H. (2017). Assessing moderation of employee engagement on the relationship between work discretion, job clarity and business performance in the banking sector of Pakistan. Asian Economic and Financial Review, 7(12), 1197-121. https://doi.org/10.18488/journal.aefr.2017.712.1197.1210

Ahmed, U., Majid, A. H. A., \& Zin, M. M. (2016). Moderation of meaningful work on the relationship of supervisor support and coworker support with work engagement. The Journal of Business, Economics, and Environmental Studies (JBEES), 6(3), 15-20.

Avalos, B. (2011). Teacher professional development in teaching and teacher education over ten years. Teaching and Teacher Education, 27(1), 10-20. DOI:

Berg, J. H., Bosch, C. A., \& Souvanna, P. (2013). Critical conditions: What teacher leaders need to be effective in schools. JSD, Learning Forward's Journal, 34(6), 26-30.

Bowman, R. F. (2004). Teachers as leaders. The Clearing House, 77(5), 187-189. DOI: https://doi.org/10.3200/TCHS.77.5.187-189

Cooper, K. S. (2014). Eliciting engagement in the high school classroom: a mixed-methods examination of teaching practices. American Educational Research Journal, 51(2), 363-402. DOI: https://doi.org/10.3102/0002831213507973

Danielson, C. (2006). Teacher Leadership that Strengthens Professional Practice. Alexandria, VA: Association for Supervision and Curriculum Development.

Fairman, J. C., \& Mackenzie, S. V. (2012). Spheres of teacher leadership action for learning. Professional Development in Education, 38(2), 189-201. DOI:

Fairman, J. C., \& Mackenzie, S. V. (2014). How teacher leader influence others and understand their leadership. International Journal of Leadership in Education, 18(1), 61-87. DOI: https://doi.org/10.1080/13603124.2014.904002

Fowler, D. F. J. (2009). Survey Research Methods. Thousand Oaks: Sage Publications.

Garvin, D. A., Edmondson, A. C., \& Gino, F. (2008). Is yours a learning organization? Harvard Business Review. March, 1-10.

Gay, L. R., Mills, G. E., \& Airasian, P. W. (2009). Educational Research: Competencies for Analysis and Applications. New Jersey: Prentice Hall.

Guskey, T. R. (2009). Closing the knowledge gap on effective professional development. Educational Horizons, 87(4), 224-233. DOI: https://doi.org/10.2307/42923773

Guskey, T. R. (2014). Planning professional learning. Educational Leadership, 71(8), 10-16.

Honan, E. (2012). A whole new literacy': Teachers' understanding of students' digital learning at home. Australian Journal of Language and Literacy, 35(1), 82.

https://doi.org/10.1016/j.tate.2010.08.007

https://doi.org/10.1080/19415257.2012.657865

Hunzicker, J. (2012). Professional development and job-embedded collaboration: how teachers learn to exercise leadership. Professional Development in Education, 38(2), 267-289. DOI: 10.1080/19415257.2012.657870

Ishak, R., \& Faizal, M. A. G. (2012). Amalan Kepimpinan terbaik untuk Sekolah "Organisasi Pembelajaran". Jurnal Pendidikan Malaysia, 37(2), 35-41.

Jabatan Pendidikan Negeri Perak. (2017). Jabatan Pendidikan Negeri Perak. 
INTERNATIONAL JOURNAL OF ACADEMIC RESEARCH IN PROGRESSIVE EDUCATION AND DEVELOPMENT

Vol. 8, No. 4, 2019, E-ISSN: 2226-6348 @ 2019 HRMARS

Katzenmeyer, M., \& Moller, G. (2009). Awakening the Sleeping Giant: Helping Teachers Develop as Leaders (2nd ed.). Thousand Oaks, CA: Corwin Press.

Kementerian Pelajaran Malaysia. (2012). Pelan Pembangunan Pendidikan Malaysia (2013-2025). Kuala Lumpur: Kementerian Pelajaran Malaysia.

Kementerian Pelajaran Malaysia. (2014). Laporan Tahunan 2014. Putrajaya: Kementerian Pelajaran Malaysia.

Lead, T.T.H.E. (2013). Your Goals. Instructor, 7-10.

MacBeath, J. (2012). Leadership for learning. The Cambridge Network, 2, 1-9.

Mansor, M., Norwani, N. M., \& Yunus, J. N. (2011). Inventori pembelajaran profesional: Pembinaan inventori, analisis faktor, kebolehpercayaan dan kesahan. Dalam Seminar Majlis Dekan-Dekan Fakulti Pendidikan IPTA 2011, Serdang: Fakulti Pendidikan, Universiti Putra Malaysia.

Marsick, V.J., \& Watkins, J.E. (2003). Demonstrating the value of an organization`s learning culture: The dimensions of the learning organization questionnaire. Advances in Developing Human Resources, 5(2), 132-151. DOI: https://doi.org/10.1177/1523422303005002002

Marzano, R.J. (2012). Teacher evaluation: What's fair? What's effective? Educational Leadership, 70(3), 14-19.

Moller, G., Childs-Bowen, D., \& Scrivner, J. (2001). Teachers of the year speak out: Tapping into teacher leadership. Greensboro. NC: South Eastern Regional Vision for Education.

Muijs, D., Chapman, C., \& Armstrong, P. (2013). Can Early Careers Teachers Be Teacher Leaders? A Study of Second-year Trainees in the Teach First Alternative Certification Programme. Educational Management Administration \& Leadership, 41(6), 767-781. DOI: https://doi.org/10.1177/1741143213494188

Nemser, F. S. (2012). Teacher as Learner. Harvard Education Press. Cambridge, Mass.

Poekert, P. (2012). Teacher leadership and professional development: examining links between two concepts central to school improvement. Professional Development in Education, 38(2), 169-188. DOI: https://doi.org/10.1080/19415257.2012.657824

Rovere. (2013). Teacher Leadership in Professional Learning Communities such as Networks. York Region District School Board.

Saad, N. \& Surendran, S. (2013). Kepimpinan Transformasional Pengetua dengan Penglibatan Guru dalam Membuat Keputusan di Sekolah. PENYELIDIKAN, 1406-1414.

Senge, P.M. (1990). The Fifth Discipline: The Art and Practice of the Learning Organization. New York: Doubleday.

Spillane, J. P. (2012). Distributed leadership (Vol. 4). John Wiley \& Sons.

Stoll, L. (2011). Leading professional learning communities. Leadership and Learning, 103-117. DOI: http://dx.doi.org/10.4135/9781473915152.n20

Swanson, J., Elliott, K., \& Harmon, J. (2011). Teacher Leaders Stories. Thousand Oaks: Corwin Press.

Watkins, E. K., \& Marsick, V. J. (1996). In action: Creating a Learning Organizations. Alexandria. VA: American Society for Training and Development.

Watkins, E. K., \& Marsick, V.J. (1993). Sculpting the Learning Organizations: Questionnaire. San Francisco: Josey-Bass. 
INTERNATIONAL JOURNAL OF ACADEMIC RESEARCH IN PROGRESSIVE EDUCATION AND

DEVELOPMENT

Vol. 8, No. 4, 2019, E-ISSN: 2226-6348 @ 2019 HRMARS

York-Barr, J., \& Duke, K. (2004). What do we know about teacher leadership? Findings from two decades of scholarship. Review of Educational Research, 74, 255-316. DOI: https://doi.org/10.3102/00346543074003255 